\title{
Dissolved organic carbon as potential indicator of global change: A long-term investigation in the northern Adriatic
}

\author{
Jelena Dautović ${ }^{\mathrm{a}}$, Vjeročka Vojvodić ${ }^{\mathrm{a}}$, Nataša Tepić ${ }^{\mathrm{b}}$, Božena Ćosović ${ }^{\mathrm{a}}$, Irena Ciglenečki ${ }^{\mathrm{a}, *}$ \\ ${ }^{a}$ Rudjer Boskovic Institute, Division for Marine and Environmental Research, Bijenička cesta 54, 10000 Zagreb, Croatia \\ ${ }^{b}$ National Center for External Evaluation of Education, Ulica D. Tomljenovića 11, 10020 Zagreb, Croatia
}

\section{H I G H L I G H T S}

- Long-term study of temporal and spatial distribution of DOC in the Adriatic Sea

- The northern Adriatic-periodically eutrophic and oligotrophic system

- DOC content in the northern Adriatic is highly affected by salinity changes.

- DOC variations as a good proxy for the BiOS

- DOC as a potential indicator of climate change

\section{G R A P H I C A L A B S T R A C T}

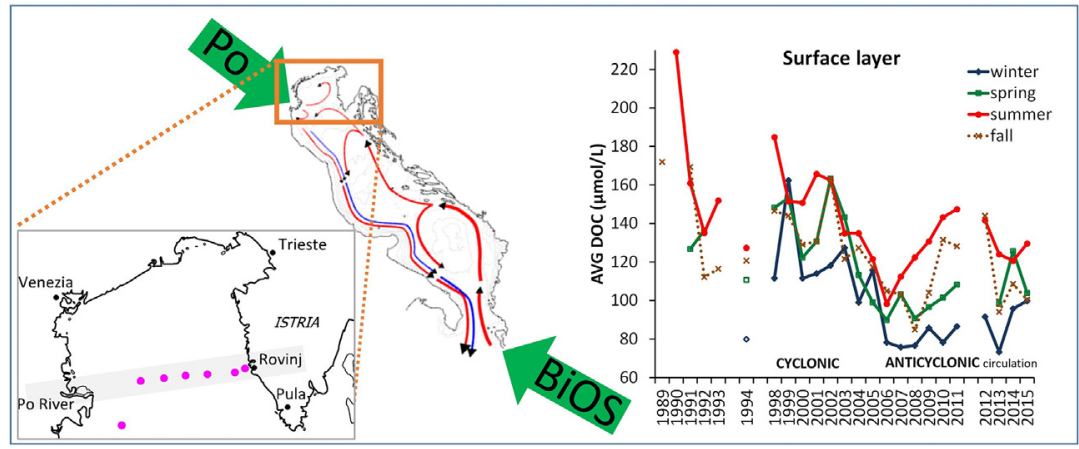

A B S T R A C T

Dissolved organic carbon (DOC) is an essential component of the biogeochemical marine system, effecting biological and chemical reactions that take place in the sea. DOC represents a dynamic component of the global carbon cycle.

This paper reports 25 years of measurements of DOC content and distribution at seven stations along the transect Po River delta - Rovinj in the northern Adriatic (NA). The results show strong temporal and spatial variability: (1) The highest average DOC concentrations were observed in 1998 and $2002(143 \mu \mathrm{mol} / \mathrm{L}$ and $137 \mu \mathrm{mol} / \mathrm{L}$, respectively); (2) The minimum average DOC was recorded in 2006 ( $88 \mu \mathrm{mol} / \mathrm{L}$ ) and (3) The short-term DOC accumulation (up to 203, average $102 \mu \mathrm{mol} / \mathrm{L}$ ) for the years 2009 to 2012, was observed during the summer and autumn months followed by unusually low DOC concentrations during the winter and spring. The DOC results from the more recent monitoring at the same stations indicate primarily oligotrophic characteristics of the NA seawater $(88 \mu \mathrm{mol} / \mathrm{L})$.

The results of DOC variability and distribution in the NA appears to be strongly influenced by complex circulation patterns. This paper provides a "link" between the Ionian circulation and the NA ecosystem as a part of the recently identified Adriatic-Ionian Bimodal Oscillating System (BiOS). A good agreement between the BiOS oscillation and other variables related to the DOC concentration, like the NA A and B winter types, the Po River discharge, salinity, chlorophyll $a$, occurrence of hypoxic-anoxic conditions, eutrophication and oligotrophication, suggests that DOC might be a good tool and indicator of global change.

\footnotetext{
* Corresponding author.

E-mail address: irena@irb.hr (I. Ciglenečki).
} 


\section{Introduction}

Primary photosynthetic production by phytoplankton in surface seawaters is the largest source of organic carbon in marine systems. Dissolved organic carbon (DOC) in the global seas is the Earth's largest reservoir of organic matter ( $640 \mathrm{Pg} \mathrm{C})$, comparable to the amount of carbon found in a pool of atmospheric $\mathrm{CO}_{2}$. It is a significant component of the biogeochemical marine system, now recognized as a possible barometer of the global change (Church et al., 2002; Ducklow, 2002). DOC represents a dynamic component of the global carbon cycle modifying many of the biological and chemical reactions that take place in the sea. It provides nutritional and energy base for micro- and macro-organisms. DOC has major impact on the speciation of many metals by complexation and adsorption processes, and it serves as a precursor for fossil fuels such as petroleum and oil shale.

Improvements in measurement precision, in particular the hightemperature catalytic oxidation method (HTCO), enabled detection of the fine temporal and spatial DOC concentration gradients and their variability. This is important for better understanding of the role of DOC in global changes in the oceans, marginal seas, and coastal areas (Williams et al., 1993; Cauwet, 1994, 1999; Hansell and Carlson, 2001).

The northern Adriatic (NA) is a semi-closed shallow basin with open and coastal waters characteristics, located north-east in the Mediterranean. The mean depth is $33.5 \mathrm{~m}$, total area $118,000 \mathrm{~km}^{2}$, and volume of $635 \mathrm{~m}^{3}$. The NA is a dynamic system strongly influenced by anthropogenic pressure and climate changes, now confirmed to be present in the Mediterranean areas (Schiano et al., 2005; Grbec et al., 2009; Giani et al., 2012; Djakovac et al., 2015). Changes in riverine inputs, particularly the Po River discharge with the mean flow rate of $1469 \mathrm{~m}^{3} \mathrm{~s}^{-1}$ (Cozzi and Giani, 2011), advection of the central Adriatic water along the eastern coast, a southerly flow in the coastal zone off Istria, the Istrian Coastal Counter Current (ICCC; Supić et al., 2000), a variable and complex circulation driven by the Adriatic-Ionian Bimodal Oscillating System, BiOS (Gačić et al., 2010, 2014), and intense air-sea interactions were suggested to play a fundamental role in physical and biogeochemical processes in the NA (Zavatarelli et al., 1998; Kraus and Supić, 2011; Djakovac et al., 2012, 2015; Kraus et al., 2016).

The NA is one of the most productive areas of the generally oligotrophic Mediterranean (Fonda Umani et al., 2005, 2007). The annual primary production rates in the NA show strong inter- and intra-annual variability, from 55 to $414 \mathrm{~g} \mathrm{C} \mathrm{m}^{-2} \mathrm{yr}^{-1}$, measured at the Po delta (Revelante and Gilmartin, 1983; Zoppini et al., 1995; Harding et al., 1999; Sellner and Fonda-Umani, 1999; Fonda Umani et al., 2007). This is often accompanied by the appearance of strong phytoplankton blooms and formation of large gelatinous-mucous aggregates recorded for the NA as far as year 1729 (Vollenweider and Rinaldi, 1995). More recently, this blooming phenomenon occurred rather frequently (1988, 1989, 1991, 1997, 2000-2004) (Iveša et al., 2016), and was often followed by an accumulation of organic matter primarily at the stratification zones characterized by pycnocline (Ciglenečki et al., 2000, 2003; Ćosović and Vojvodić, 2000; Giani et al., 2005).

Significant changes in the NA physical and biological conditions for the past 30 years were reported indicating a process of oligotrophication during the last decade (Mozetič et al., 2010; Djakovac et al., 2012, 2015; Gašparović, 2012; Giani et al., 2012; Colella et al., 2016; Iveša et al., 2016). These observations are consistent with the results of the Intergovernmental Panel on Climate Change, IPCC report (IPCC, 2013), showing that the climate in the Mediterranean region is changing. Significant changes in DOC have been recognized as a possible indicator of long-term biogeochemical- and climate-induced variabilities (Hansell and Carlson, 2015).

Rising atmospheric $\mathrm{CO}_{2}$ levels and climate change associated with concurrent shifts in temperature, circulation, stratification, nutrient input, oxygen content and ocean acidification could have potentially wide-ranging biological effects (Grbec et al., 2009 and references therein). Changes in temperature and $\mathrm{pH}$ could have synergistic negative effects on species composition and growth, survival and development (Noone et al., 2013). Both organisms and ecosystems are changing in response to ocean warming, acidification, and de-oxygenation. That reflects on primary production, and further on organic matter content and composition in the oceans, by changing the ratio between the DOC fraction and the particulate organic carbon (POC) fraction (Wakeham and Lee, 1993).

A comprehensive study of DOC in specific areas of the NA basin and different periods has been conducted since 1989 (Vojvodić and Ćosović, 1996; Pettine et al., 1999, 2001; Giani et al., 2005, 2012). While riverine/ estuarine environments were extensively studied with focus on investigation of long-term organic matter (1997-2010) (Wu et al., 2015), similar DOC data are scarce for the marine environment including the NA (Pettine et al., 1999; Berto et al., 2010; Giani et al., 2005; De Vittor et al., 2008). Studies by Giani et al. (2005) and De Vittor et al. (2008, Gulf of Trieste) are the only studies that describe long-term distribution of DOC in the NA, but over a shorter time period. In the Mediterranean Sea, one Dyfamed station in the Ligurian Sea has been studied 3-years (Avril, 2002). Globally, a long-term investigation of organic carbon was carried out at a single ALOHA station (Ducklow et al., 2009), thus not providing information on its spatial pattern that was the aim of this work.

This paper describes the results of 25-years (1989-2015) observations of temporal and spatial distribution of DOC at seven stations along the transect Po River delta - Rovinj in the NA (Fig. 1). The paper examines the complex spatial (horizontal and vertical), as well as temporal (seasonal and annual) DOC distribution with several linear and quadratic random coefficient models to confirm main trends. In a longitudinal analysis, observations (statistical) are made at units, in this case, station-specific sequences of time points, so units are occurring naturally in clusters. The main idea is that observations within a cluster tend to be more similar than observations in general. The observed DOC data were primarily discussed in relation to the recently reported the NA local hydrographic and water circulation conditions (Civitarese et al., 2010; Gačić et al., 2010, 2014; Djakovac et al., 2012, 2015; Kraus and Supić, 2011; Supić et al., 2012; Mihanović et al., 2013, 2015; Janeković et al., 2014; Kraus et al., 2016).

\section{Materials and methods}

\subsection{Sampling}

Seawater samples were collected by Niskin samplers in dark $1.3 \mathrm{~L}$ bottles. Filtration was performed on-board the cruise vessel mostly within the $4 \mathrm{~h}$ after the sample collection. In-line filtration of the samples was performed on glass fibre GF/F filters (Whatman, pore size $0.7 \mu \mathrm{m})$ in all-glass filter holders under the pressure $<5$ psi. Sub-samples of the filtrate were collected in $20 \mathrm{~mL}$ glass vials, preserved with $100 \mu \mathrm{L}$ of mercury (II)-chloride solution (10 mg/L), closed with Teflonlined screw caps and stored in the dark until analysis.

Glassware used for the sampling and sample filtration were washed with chromic-sulphuric acid and rinsed well with organic-free Milli-Q water (Millipore) and seawater samples. Glass vials and Whatman GF/ F filters were combusted at $450{ }^{\circ} \mathrm{C}$ for $4 \mathrm{~h}$.

Continuous monitoring of DOC in the NA started in 1989. Monitoring frequencies and cruise plans varied from year to year (Table 1, Fig. 1): during the first 6 years $(1989,1990,1991,1993,1995,1997)$ sampling was done sporadically, mostly in summer (Period I); in year 1994 and during the period 1998-2011 the samples were collected approximately once a month, and more frequently in months characterized with an unusually high organic content and specific biological conditions (Period II). During the last three years (from the summer of 2012 until the end of 2015) the monthly sampling regime was followed, but only at 3 stations (SJ107, SJ101 and SJ108) (Period III), Fig. 1.

Period of 15 years (1994; 1998-2011 - Period II) was chosen for detailed statistical analysis. Seven stations placed on transect Po River 


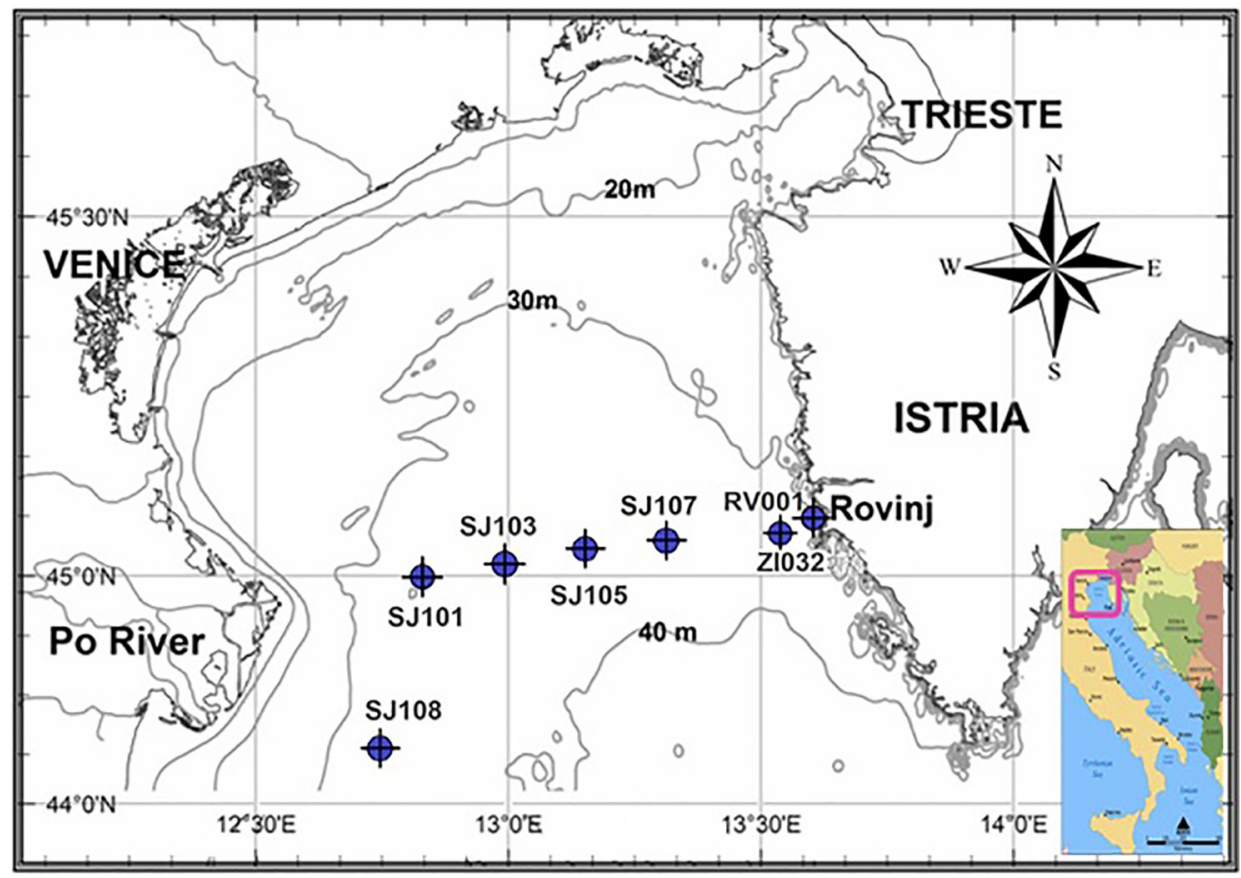

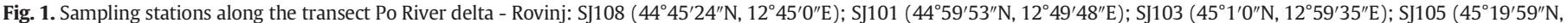

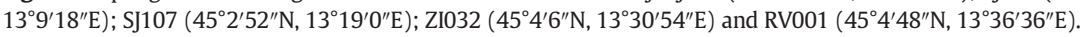

delta - Rovinj (SJ108, SJ101, SJ103, SJ105, SJ107, ZI032, RV001; Fig. 1), each with five depths ( $0 \mathrm{~m}, 5 \mathrm{~m}, 10 \mathrm{~m}, 20 \mathrm{~m}$, bottom), were sampled for the examination of spatial patterns. The seasonal pattern was examined in accordance to the other NA studies (Giani et al., 2005; Tepić et al., 2009; Gašparović, 2012): spring = March, April and May; summer = June, July and August; autumn = September, October and November; winter $=$ December, January and February.

\subsection{Analytical methods}

\subsubsection{DOC determination}

DOC concentrations were determined using the sensitive High-Temperature Catalytic Oxidation (HTCO) method at $680{ }^{\circ} \mathrm{C}$ (Cauwet, 1994 , 1999; Sharp et al., 1995; Dafner and Wangersky, 2002). Shimadzu carbon analysers, TOC 500 (years 1989-2000) and TOC-V $\mathrm{CPH}_{-} 5000$ (from year 2000) with Pt/Silica catalyst (from year 2007, Elemental microanalysis; before the high sensitivity Pt-Quartz wool catalyst, Shimadzu) and Non-Dispersive Infrared (NDIR) detector for $\mathrm{CO}_{2}$ were used for DOC measurements. In both periods, TOC instrumentations and measurements were checked by standard analytical procedures including validation, international and inter-laboratory comparison and inter-calibration, to ensure that DOC data for all 25 years presented here are valid, reliable and comparable. A fraction of these data was published before as a part of the MAT project (Giani et al., 2005).

Milli-Q water was used to assess the instrument blank and for the preparation of calibration solutions. Values adjusted for the blank were based on the $50 \mu \mathrm{L}$ sample volume and had a significant precision $(1-2 \mu \mathrm{mol} / \mathrm{L}$ org C). Three to four data points were used for the calibration curve with potassium hydrogen phthalate in the concentration range $0-5 \mathrm{mg} / \mathrm{L}$. Samples were acidified to $\mathrm{pH}=2$ with $2 \mathrm{mmol} / \mathrm{L} \mathrm{HCl}$ and purged with pure air for $10 \mathrm{~min}$ prior to analysis in order to eliminate the inorganic carbon. The concentration was calculated as an average (AVG) of three to five replicates with coefficient of variation $<2 \%$ and standard deviation $<0.1$. The AVG instrument blank and Milli-Q blank corresponded to $2.5 \mu \mathrm{mol} / \mathrm{L}(\mathrm{n}=32)$; the reproducibility of measurements were high $(1.6 \%)$.

Temperature and salinity were determined by CTD probe (SBE 25 Sealogger CTD, Sea-Bird Electronics, Inc., Bellevue, Washington, USA) and were provided for all analysed samples by the Center for Marine Research, IRB, Rovinj, Croatia.

\subsubsection{Statistical analysis}

Data were analysed by SAS/STAT ${ }^{\circledR} 13.2$ and SAS/QC ${ }^{\circledR} 13.2$ software (Version 9.4, SAS System for Windows., Copyright ${ }^{\complement}$ 2002-2012 SAS Institute Inc.). Boxplots were generated using PROC SHEWHART with boxchart statement.

To investigate curve parameters for the DOC data along temporal and spatial component, a random coefficient model was used (Littell et al., 1996) because of the relatively high intra-class correlation coefficient $($ ICC $=0.686$ ) that indicates substantial inter-observer agreement (Landis and Koch, 1977) and justifies the use of this particular modelling approach. The random coefficient model was utilized using the PROC MIXED procedure with REML estimation method and unstructured covariance (option type $=\mathrm{UN}$ in random statement). With the same procedure intra-class correlation coefficient is calculated to show the fraction of the total variation of the data that is accounted for by the between-group variation. All DOC data were logarithmic transformed to achieve the assumption of normality. Additionally, continuous predictor variables were grand-mean centred (Enders and Tofighi, 2007; Hofmann and Gavin, 1998) in order to ensure numerical stability in estimating hierarchical linear models. All testing was performed at the 0.05 level of significance.

\section{Results}

\subsection{Descriptive statistics}

The whole dataset (years 1989-2015) consists of 6539 DOC values, while Period II subset, that was subjected to detailed statistical analysis, incorporates 5608 DOC observations. The majority of DOC values are quite low - the minimal (Q0) DOC value was $62 \mu \mathrm{mol} / \mathrm{L}$ (ZI032 bottom, summer 2008) and $87 \mu \mathrm{mol} / \mathrm{L}$ for the first quartile (Q1; the lowest $25 \%$ of the data, Table S1, Supplemental material). Even the DOC data for the third quartile (Q3; 75\% of all data) were $<125 \mu \mathrm{mol} / \mathrm{L}$. The higher AVG values then medians (Q2; the lowest $50 \%$ of data), as well as boxplots (Figs. 2 and 3), indicate positive asymmetry that is in 


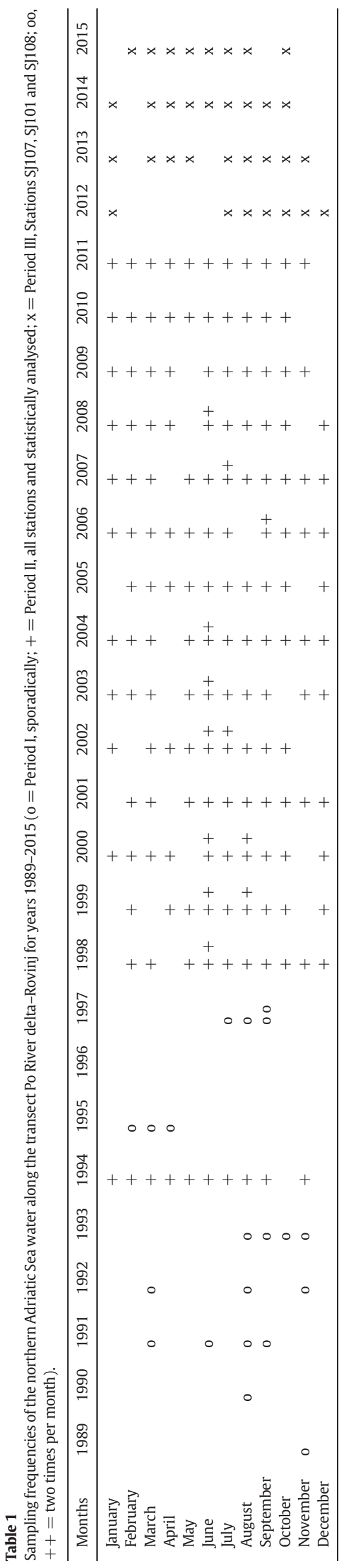

concordance with the maximal (Q4) DOC values. The value for Q4 ( $596 \mu \mathrm{mol} / \mathrm{L}, \mathrm{SJ} 1035 \mathrm{~m}$, summer 1998) is 9.5-times higher than for Q1 $(62 \mu \mathrm{mol} / \mathrm{L})$ and 5.7-times higher than for Q2 $(104 \mu \mathrm{mol} / \mathrm{L})$. The range for the highest $25 \%$ of the data (Q4-Q3) is 7.7-fold of the range for the lowest $75 \%$ of the data (Q3-Q0). The highest $25 \%$ of the data (Q4-Q3) is the most variable part of the investigated DOC data.

Comparing descriptive statistics of the complete dataset with statistics by the transect (Fig. 2a and Table S1, Supplemental material) any remarkable deviation from the previously described pattern is not recognized. All statistics, except for Q4 and Q3, are quite uniform with the small reduction in DOC values from station SJ103 towards the eastern part of the basin (stations ZI032 and RV001) (Fig. 2a).

A little discrepancy was noticeable with respect to the vertical DOC distribution. Highest DOC values were observed in the uppermost $10 \mathrm{~m}$ of the seawater with decreasing trend towards the sea bottom (Fig. 2b). The first quartile, median and AVG DOC are somewhat higher for the upper water layers than for the water samples collected at other depths at each station (Table S1, Supplemental material). The Q2 at $0.5 \mathrm{~m}$ and $10 \mathrm{~m}$ is $119 \mu \mathrm{mol} / \mathrm{L}$ and $112 \mu \mathrm{mol} / \mathrm{L}$, respectively. However, $>75 \%$ of the DOC values at $20 \mathrm{~m}$ or near the bottom are below these values. Furthermore, $29 \%$ of the surface layer DOC data and $62 \%$ of the bottom layer DOC data were below $100 \mu \mathrm{mol} / \mathrm{L}$. Almost identical DOC values for the surface water layer were measured during the summer. This period is characterized with the highest overall DOC values for the location. In contrast, winter was the season with the lowest DOC values. The percent of non-missing observations less than $100 \mu \mathrm{mol} / \mathrm{L}$ (interval with the most frequent DOC values ) for winter is 65\%, for summer only $28 \%$, and for the whole dataset is $~ 31 \%$. Unlike the other quintiles (Q1, Q2, Q3), Q4 value for winter (334 $\mu \mathrm{mol} / \mathrm{L}$ ) was higher than that for the spring ( $289 \mu \mathrm{mol} / \mathrm{L}$, Table S1, Supplemental material).

Descriptive statistics and boxplots by stations, depths, seasons and years (Figs. 2 and 3), indicate that the NA basin is quite dynamic.

Annual distribution of DOC alternated between two groupings: the first group, years 1998-2003, is characterized by the higher DOC values ( $75 \%$ of all values are higher than $100 \mu \mathrm{mol} / \mathrm{L}$ ); the second group, years 1994 and $2004-2011$, had lower values ( $50 \%$ of all values were lower than $100 \mu \mathrm{mol} / \mathrm{L}$ ). The most illustrative years are 1999 and 2002 for first group and 2006 and 2008 for the second group. The widest annual quartile ranges are between the third and the fourth quartile with the

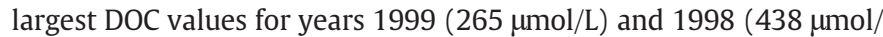
$\mathrm{L}$ ). The variability inside the particular year is rather specific. For example, the range (Min to Max) for the year 2009 is only $78 \mu \mathrm{mol} / \mathrm{L}$ or 6.5 times less than the range for the year 1998 (510 $\mu \mathrm{mol} / \mathrm{L})$. In addition, there are differences among the Q0 values for the particular years: the minimal Q0, $87 \mu \mathrm{mol} / \mathrm{L}$, in year 2000 is $40 \%$ higher than the maximal $\mathrm{Q} 0,62 \mu \mathrm{mol} / \mathrm{L}$, in year 2008. All these suggest a different behaviour of DOC complete subgroups and not only of some isolated subgroup parts. Therefore, the need for further analysis was accordingly justified.

Distribution of DOC within the water column of all studied stations along the transect for the three characteristic years $(2002,2006,2009)$ are presented in Fig. S1 (Supplemental material). These years are by the statistics underlined as different: year 2002 with the high DOC of significant variability within the water column and expressed water column stratification; year 2006 with the low DOC and low variability within the water column; and year 2009 with accumulation of DOC during the summer and autumn.

\subsection{Random coefficient models}

Statistical models were used to investigate and confirm previously observed main DOC trends during the Period II (years 1994 and 19982011) (Vojvodić and Ćosović, 1996; Pettine et al., 1999; Giani et al., 2005, 2012), as well as the DOC patterns from Section 3.1 above. Many standard statistical methods (e.g. analysis of variance (ANOVA) and regression) have the key assumption of an observational independence. As a result, these models are not suitable for longitudinal data 

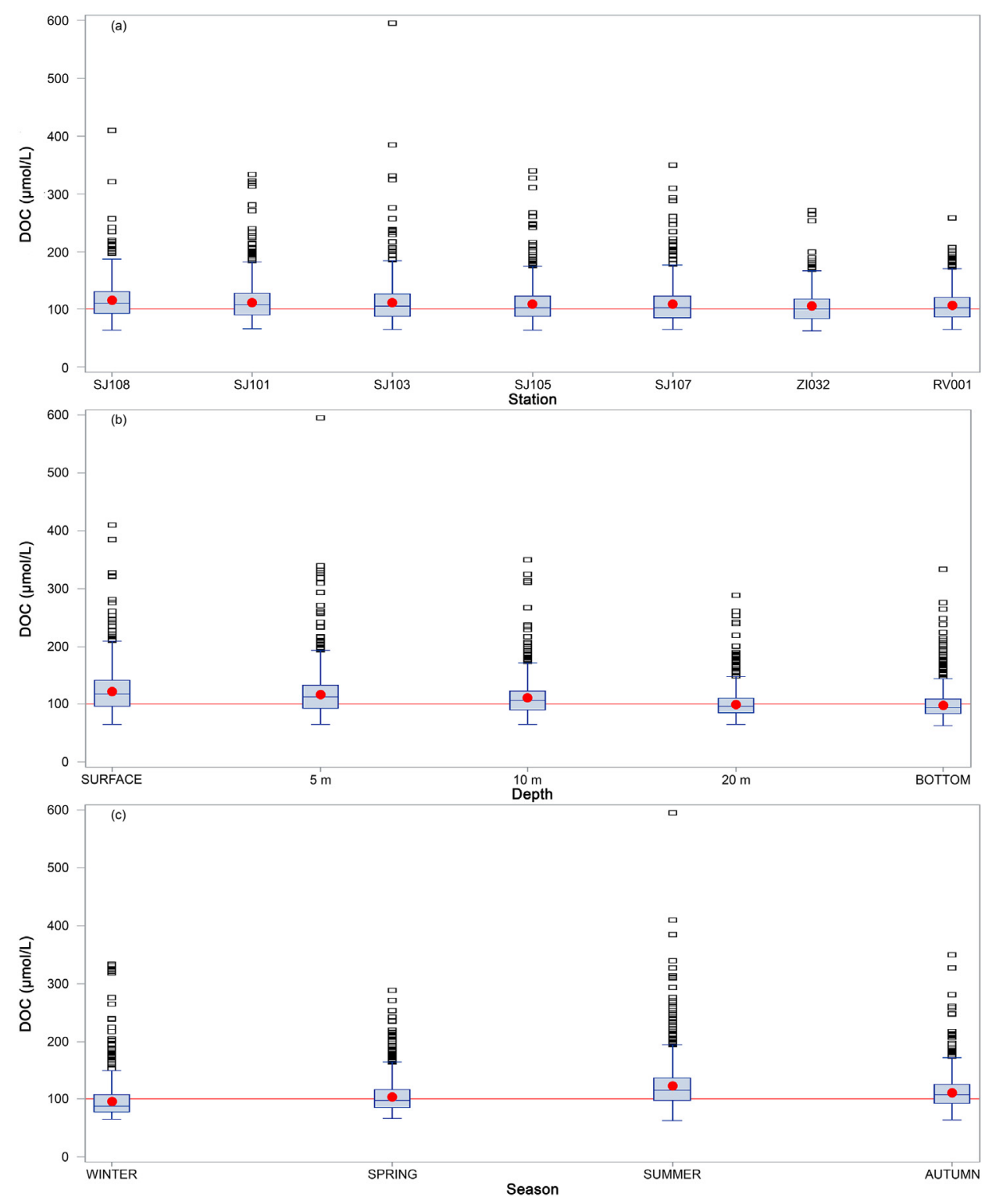

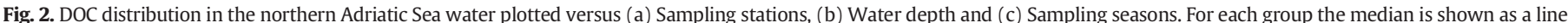

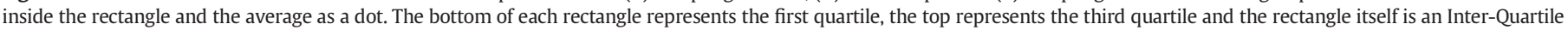

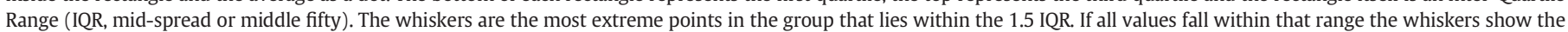

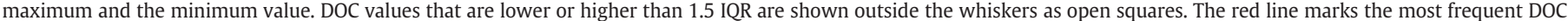

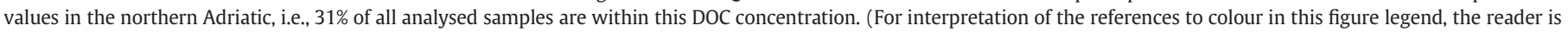
referred to the web version of this article.)

analysis. However, the mixed model and its special case - the hierarchical linear model (or multilevel model) are built to allow within- and between-cluster variation, so these models are a natural choice for investigation in longitudinal and spatial studies, as was done here.

In the random coefficient model, each station is represented with its own trajectory. Often, each trajectory is almost identical to trajectories of all other stations. Consequently, global trajectory, which includes all stations, would represent well all trajectories for every individual station (there is no statistically significant differences in intercepts and/ or slopes) and it could be concluded that the spatial component well describes data for all stations. However, it is possible for each station's trajectory to have its own parameters, which are different (positive or negative) from the global. In cases like this, it is justified to assume the existence of some additional influence which is necessary to incorporate in the model in order to better describe the data.

Initially, the complete dataset was analysed to detect a possible additional influence on horizontal spatial component (the transect Po
River delta - Rovinj, without the station SJ108) due to prior knowledge (Vojvodić and Ćosović, 1996; Pettine et al., 1999; Giani et al., 2005, 2012). DOC concentrations were modelled by the change of the distance from the Po River mouth (Model I). Slopes of the curves for the each sampling are generally negative (not shown here), indicating that the DOC concentrations were decreasing from the western towards the eastern part of the transect. All fit statistics, ( -2 Res Log Likelihood, Akaike's information criterion (AIC), corrected Akaike's information criterion (AICC) and Bayesian information criterion (BIC) are in the range from 32437 to 32450 depending on the statistics. In addition, the aggregated findings of that model are shown in Table S2 (Supplemental material). Evidently, there are numerous DOC samplings characterized with aberrations from global parameters. Besides different aberration frequencies by years, the intercept aberrations $(n=132)$ are more common than the slope aberrations $(n=28)$, and the number of positive $(n=67)$ and negative $(n=65)$ intercept aberrations are almost identical ( $n=37$ ), as well as the slope aberrations ( $n=14$ for both). 


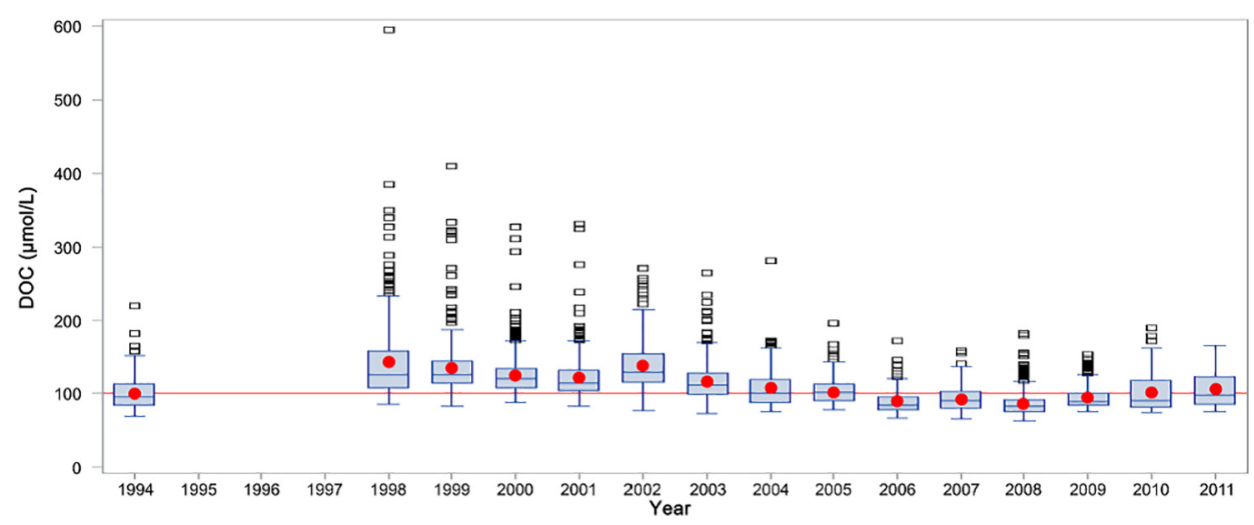

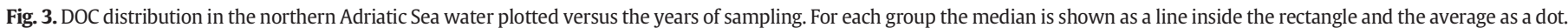

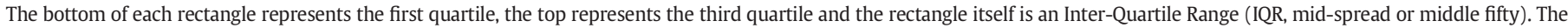

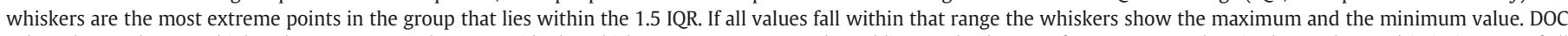

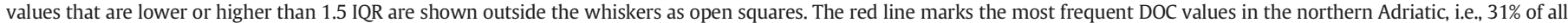
analysed samples are within this DOC concentration. (For interpretation of the references to colour in this figure legend, the reader is referred to the web version of this article.)

The more frequent intercept aberrations indicate uniform changes in DOC concentrations along the whole transect, while the slope aberrations indicate changes in local, isolated part of the transect. Years characterized with a lot of aberrations are the most interesting. More detailed exploration of Table S2 (Supplemental material) confirmed our expectations, the previous knowledge and the pattern noticed in Fig. 3. The period from 1998 to 2002 (except year 2001) is characterized by the majority of samplings with positive intercept aberrance (71$100 \%$, Table S2, Supplemental material) - meaning that the DOC values along transect within individual sampling campaign were significantly higher than the values from the global trajectory. In contrast, the period from 2006 to 2008 is typified by the negative intercept aberrance for the most of sampling campaigns (67-100\%, Table S2, Supplemental material). The other years are representative examples of more complex behaviour in which alternate both negative and positive intercept aberrances from the global trajectory. Slope aberrances are quite rare; 2006, 2009, 2010 and 2011 are years without any slope aberration. The year with the maximal amount of slope aberrances (50\%) is 2003. The proportions for negative aberrances are $0 \%-33 \%$ and up to $18 \%$ for the positive aberrances (Table S2, Supplemental material). Our model confirmed an overall DOC change and not increasing of the few extreme DOC values.

To check for the consistency of the previously described pattern within separated water layers, the five sub-models were used, one for each water depth (Models II). Their fit statistics are in the range of 6485to 6933. Skimming of Table S3 (Supplemental material) substantiates previously described findings (no significant positive intercepts for the 2006-2008 period; no significant negative intercepts for 1999 and 2002), but a closer look revealed few differences. The individual sampling intercepts from 1999 and from 2002 year are largely (73-100\%) significantly higher than the global one, without any exception with significant, negative intercepts. Few negative intercepts in the surface layer with predominant significant positive intercepts are characteristics of 1998, 2000 and 2001 year. Remaining years are marked with at least $25 \%$ of intercept aberrances and mixture of positive and negative intercept aberrances. The 2002 year is the year with the lowest amount of non-significant intercepts - even 20 m layer has only $18 \%$ while $10 \mathrm{~m}$ and bottom layer have $0 \%$.

Obviously, DOC distribution in separate water layers is rather complex and under the influence of some additional parameters, so the existing model was expanded to include seasonality (Models III). This has resulted in a small, additional reduction of fit statistics (6476$6880)$. Notwithstanding, yet there is a notable body of significant intercept aberrations; from $5.8 \%$ to $6.7 \%$ for the negative intercept aberrations within the individual depth model, and from $4.9 \%$ to $6.0 \%$ for the positive. The negative slope aberrance proportions are about 10-times lower $(0.2 \%-0.8 \%)$ than for the intercept, and the positive slope aberrance occurred only for $20 \mathrm{~m}$ water layer.

Concurrently to spatial dependency models, after expansion of extra sub-models by every category within the season (Models IV), better models were developed, what is noticeable from the all fit statistics reduction to only 1345-2364. Although fit statistics reduction suggested optimal model for the DOC data, the individual trajectories contradict this. As in the previous models, significant intercept aberrations, either positive or negative, are the most frequent (up to $2 \%$ at the bottom water layer in summer). The minimal number of deviations are in the $0.5 \mathrm{~m}$ water layer during the autumn (1\%). As opposed to intercept aberrations in the previous models, the slope aberrations are quite often; only 3 models do not have any negative slope aberrations and all 3 are from the spring. In case of positive slope aberrations, there are 10 models without any aberration at all, an increase compared to the prior models.

The minimization of the all fit statistics by several times (from roughly 32500 to only 1340) supports superiority of the final model over the starting one, but the increasing of the aberration amount suggested a need for additional options. After focusing on spatial dependencies, supplementary approach for the identification of temporal influenced was implemented. The order in the hierarchy was switched, and the emphasis was on temporal component. Data within the individual water layer were modelled as the year days (continuous approach), an alternative to the four seasons categorical approach. The station SJ108 is included in this particular model but the easternmost stations ZI032 and RV001 are not. The linear models (Models V) were adequate to describe the data from all water layers except the surface layer. The often approach to repeated measures with random coefficient is based on polynomial trend models as polynomial functions of time, what is relevant for the DOC surface layer data in this case. Obviously, DOC variation in the surface water column during the year is so pronounced that the model with quadratic members better describes the data. The all fit statistics are larger (5611-5619) than those of the models with the categorical seasonal approach $(\sim 1340)$, but the quantity of the data is 4times higher (822 versus $\sim 200$ ).

\subsection{Comparison with recent years}

In the last few years (2012-2015, Period III) of the DOC monitoring the number of the sampling stations decreased. The DOC measurements continued at 2 westernmost stations (SJ108, SJ101) that are under the direct influence of the Po River, and 1 easternmost station (SJ107), that is more influenced by the open waters with the higher salinities (Djakovac et al., 2012). Period III was not included in the detailed statistical part of the study (done by random coefficient models), because of 
the different sampling regime, but it was used to show the most recent trends in the NA system.

The average seasonal DOC in the surface water layer at all stations along the studied transect, for the entire period of investigation 19892015, is shown in the Graphical abstract. Standard deviations for the seasonal values are given in Table S4 (Supplemental material).

The average surface DOC analysis shows that during the entire period of the investigation the NA was a highly dynamic system with periods of high and low DOC content that is consistent with the results of the statistical analysis of a Period II. The highest AVG DOC was measured in the summer of 1990, followed by a period of significant DOC accumulation accompanied with the appearance of mucilaginous aggregates (2000-2004). However, it is important to keep in mind different sampling regimes with significantly smaller number of data in the period before 1993 (see Section 2.1 Sampling, Table 1). Minimum AVG DOC was measured in 2006. A slight increasing trend is observed from 2006 until 2011. Recent years (2012-2015) are characterized by relatively low DOC content that are in line with the oligotrophic characteristics of the NA water column (AVG DOC $88 \mu \mathrm{mol} / \mathrm{L}$ ) reported for the earlier period (2000-2009, Mozetič et al., 2010; Djakovac et al., 2012; Gašparović, 2012; Catalano et al., 2014; Colella et al., 2016), and for the more recent period up to year 2013 (Iveša et al., 2016).

\section{Discussion}

The random coefficient models used in this study have confirmed existence of the patterns obtained using simpler methods in the previous studies (Vojvodić and Ćosović, 1996; Pettine et al., 1999; Giani et al., 2005, 2012). Results of statistical analysis revealed a strong vertical and horizontal spatial variability, as well as the seasonal and inter-annual variability. The main patterns are: 1) Decrease in DOC with seawater column depth; 2) Decrease in DOC from the western towards the eastern part of the basin; 3) Accumulation of DOC during the summer followed by a gradual DOC depletion in winter; 4) Seasonal influence appear to be the most prominent in the surface water; and 5) The strong inter-annual variability is very prominent.

The seasonal signal is dominant in the uppermost seawater layer and its pattern is under the influence of the quadratic member. In contrast, seasonality in the bottom seawater layer is accurately described without a quadratic member. DOC values varied from year-to-year, but the hypothetical regular annual cycle of DOC distribution could have been investigated only by analysing a longer observational dataset.

The DOC seasonality here was defined as is usually for the Adriatic (Vojvodić and Ćosović, 1996; Giani et al., 2005; Tepić et al., 2009; Ciglenečki et al., 2015), considering that the seasons were similar for the terestial ecosystems. Even though there is evidence that the seasons in the sea could be as much as one month delayed with the respect to the seasons on the land, the DOC seasonality defined that way (Artegiani et al., 1997) did not show a different picture (data not shown). That suggest that both seasonal definitions, at least in the case of the DOC distribution in the NA, could be operative.

The results of this long-term study of DOC in the NA show strong spatial, seasonal and inter-annual variability in DOC content during the entire period of investigation. Alternating periods of relatively high DOC concentrations ( $600 \mu \mathrm{mol} / \mathrm{L}$, average $121 \mu \mathrm{mol} / \mathrm{L}$ for 1989 1993 and 1998-2004) and relatively low DOC concentrations $(\sim 200 \mu \mathrm{mol} / \mathrm{L}$, average $88 \mu \mathrm{mol} / \mathrm{L}$ in 2006$)$ with clearly visible decreasing trends from 1990 to 2015 (Fig. 3, as well data in the Graphical abstract and Table S1, Supplemental material) support the thesis of oligotrophication in the NA already reported by other authors (Mozetič et al., 2010; Djakovac et al., 2012, 2015; Gašparović, 2012; Catalano et al., 2014; Iveša et al., 2016; Colella et al., 2016). Statistical models have shown that changes in DOC concentrations in the NA system are mostly season dependent, thus supporting previous observational and modelling results (Pettine et al., 2001; Polimene et al., 2007; Giani et al., 2005, 2012 and references therein). The highest
DOC content was recorded during the summer months followed by autumn, spring and winter.

Alternating periods of high and low DOC content, especially during the Period II $(1994,1998-2011)$ appear to be closely related to the local Adriatic hydrographic conditions (Oddo and Guarnieri, 2011). Changes in the Po River regime and the ICCC (Supić et al., 2000) including a wide Adriatic water circulation driven by the recently discussed BiOS (Gačić et al., 2010; Civitarese et al., 2010) are the main characteristics of the NA hydrodynamics. The long-term variation in nutrients (Djakovac et al., 2015), phytoplankton (Marić et al., 2012, 2013; Kraus and Supić, 2011; Kraus et al., 2016), seasonal accumulation of organic matter and occurrence of hypoxic events in the open NA water areas (Djakovac et al., 2015) are shown to coincide with the formation of cyclonic or anti-cyclonic gyres, whose stability was estimated by the appearance of the ICCC (Djakovac et al., 2015).

However, averaging of data collected at stations that are under different environmental regimes e.g. within and out of different the NA gyres, can lead to under/over estimation of important processes which take place in the region. In addition, variability in the NA environment is induced by the changes in the Ionian Sea circulation (Civitarese et al., 2010; Batistić et al., 2014).

The interaction between the Ionian Sea and the Adriatic Sea is intimately linked by means of the BiOS mechanism that changes on a decadal time scale the upper-layer circulation in the Ionian Sea, from cyclonic to anti-cyclonic and vice versa (Gačić et al., 2010; Civitarese et al., 2010). Anti-cyclonic circulation brings a low-salinity Modified Atlantic Water (MAW) into the Adriatic, while the Levantine Intermediate Water (LIW) is advected during the cyclonic circulation. The anti-cyclonic gyre was evident in year 1994 in the northern Ionian Sea (Gačić et al., 2010). It started to weaken in year 1995, and in 1998 a fully developed cyclonic circulation was evident throughout the basin. At the same time the salinity of the seawater overall increased in the Adriatic, including the NA (Fig. 4a and c). According to data presented here, DOC content in seawater appears to be closely related to the salinity, mainly controlled by the Po River inflow and different types of waters advected into the Adriatic. That pattern was dependent on the circulation regime in the Ionian Sea controlled by the BiOS. As shown in Fig. 4b DOC amounts are dependent on the salinity and the potential density trends of the seawater layer (200-800 m) in the southern Adriatic (Fig. 4c), as well the NA average bulk salinities (Fig. 4a). It appears that DOC values were inversely proportional to the salinity. In general, when salinity was increasing the DOC values were decreasing (Fig. 4, a-c) during the cyclonic BiOS circulation (years 1998-2006) that persisted until the year 2006. In addition, the concentration of phosphate and chlorophyll $a$ was lower in the period of higher seawater salinities recorded in years 2000-2009 (Djakovac et al., 2012; Giani et al., 2012). During the same period the ICCC, shown to be correlated with the phytoplankton activity (Kraus and Supić, 2011; Supić et al., 2012) and accumulation of the organic matter, was less frequent (Djakovac et al., 2012, 2015).

Higher water salinities in the NA in years 2000-2009, as stated by Djakovac et al. $(2012,2015)$ were due to the strong reduction of the Po River flow rate and different circulation regime with frequent inflow of highly saline and oligotrophic water from the central Adriatic. The change in circulation is evidenced by the lower frequency of the ICCC with respect to the Eastern Adriatic Current (EAC) after the year 2000, particularly in spring. Increase in EAC after the year 2000 appears to be related to the cyclonic BiOS and LIW inflow into the Adriatic. Moreover, the analysis of the NA salinity trends over the last 30 years shows an increase in the seawater salinity and a clear reduction in concentrations of phosphate and ammonia in the coastal and open water areas (Solidoro et al., 2009; Djakovac et al., 2012). Years 2002 and 2006 belong to the same high salinity period 2000-2009, but are examples of two different patterns (underlined by statistics, Table S1 and S2, Supplemental material) of seasonal salinity changes, as shown for the station SJ105 in the middle of the studied transect, Fig. 4d. High variation of salinity within the seawater column enabled a stronger 


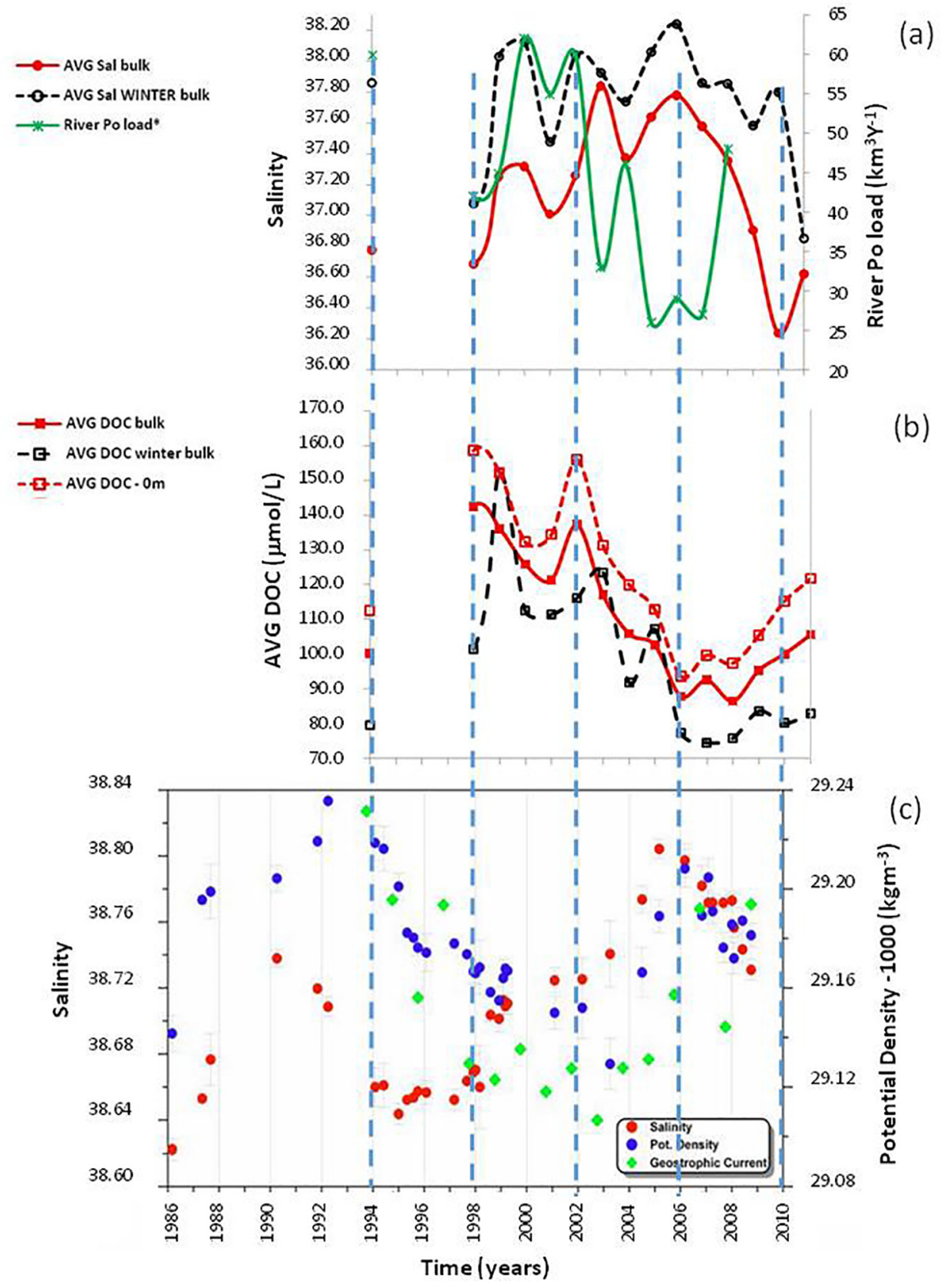

a)

(b)

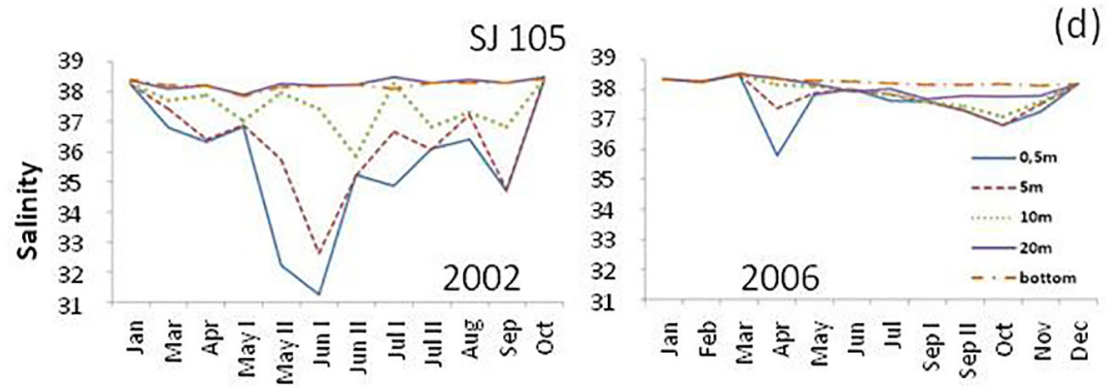

Fig. 4. (a) Relationship between the AVG bulk salinity of the northern Adriatic Sea water for winter months (black circles) and AVG bulk salinity for all 4 seasons (red circles) for the period 1994-2011, and the Po River load (green crosses, from Cozzi and Giani, 2011) for the period 1994-2009; (b) Relationship between the AVG bulk DOC concentrations in the NA seawater for the winter months (black open squares) and for all 4 seasons (red squares), and the DOC data for the surface waters (red open squares) for the period 1994-2011; (c) AVG salinity, potential density and geostrophic current in the southern Adriatic Sea (adopted from Gačić et al., 2010); (d) Salinity in the water column at the station SJ105 in the northern Adriatic Sea during the two years characterized by different BiOS circulation. (For interpretation of the references to colour in this figure legend, the reader is referred to the web version of this article.) 
column was measured at the same station in year 2006. Years 2002 and 2009 were underlined as years with the high flow rate peaks of the Po River while year 2006 had extremely low flow rates (Djakovac et al., $2012,2015)$. The selected years also differ in the intensity of the ICCC and its decreasing trend was noticed for the same period before (Djakovac et al., 2015).

This long-term study of DOC in the NA also indicates changes in DOC concentration during the winter season throughout the studied period (data in the Graphical abstract and Fig. 4b). It is apparent that years 1998-2005 were characterized by the relatively high DOC content and high variability through the water column. During these winters the higher discharge rates of the Po River and the BiOS-driven cyclonic circulation took effect that consequently resulted in the higher water salinities. Several episodes of higher discharge of the Po River (Cozzi and Giani, 2011) that decreased the salinity levels were also recorded (Fig. 4a). Winters after year 2006 had, in general, reduced discharge of the Po River and the BiOS anti-cyclonic circulation that advected low saline waters into the Adriatic. Seawater samples from these winters are characterized by the relatively low DOC content and the lack of DOC accumulation and variability through the water column.

DOC results for the period 1994-2006 (Fig. 4b) was well correlated with the analysis of the meteorological conditions and the geostrophic circulation for the preceding autumns, particularly B type winters reported by Supić et al. (2012). Winter types A and B were identified on the basis of the bottom density differences between the eastern and the western part of the NA. During the winters type A $(1993,2001$, 2004 and 2007) the seawater salinity was lower and the phytoplankton production was higher than during the most frequent type B winters (1987, 1990, 1991, 1994, 1999, 2000, 2003, 2005, 2006), indicating that the impact of the Po River waters on the NA was more pronounced during the type A winters. The abundance of the phytoplankton in the type A winters was much higher than in the type B winters, especially in the eastern part of the NA (Supić et al., 2012). However, in the type $B$ winters the Po River waters were reported to be retracted from the NA, while the waters from the southern part of the Adriatic entered the region (Supić et al., 2012).

The long-term study of DOC presented here generally shows type B winters to be characterized by the relatively higher DOC content as well as evident DOC accumulation than the winters of type A (Fig. 4b), indicating prevailing influence of the BiOS on the DOC distribution in the NA. Thus, the presence of the specific A or B winter circulation patterns seems to be closely related to the specific type of the Ionian circulation, i.e., BiOS (Gačić et al., 2010) as already hypothesized by Supić et al., 2012.

The winter DOC content in the NA was very low $(76-78 \mu \mathrm{mol} / \mathrm{L})$ for years 2006-2008 with only minor DOC accumulation. These DOC values were even lower than the DOC concentration detected in winter 1994 which was the year with the lowest DOC measured ever in the NA (data in the Graphical abstract and Fig. 4b) (Pettine et al., 2001, this study). This could be the result of the changes that happened in the NA ecosystem and were discussed before in this paper. These changes (nutrient availability, low chlorophyll $a$, shift towards larger winter bioproduction and smaller phytoplankton species) already discussed as the consequence of different water circulations, directly reflect the evidenced reduction in DOC in the NA. So far, a decreasing trend of the freshwater discharge since the 1980s (Cozzi and Giani, 2011), and the $50 \%$ reduction of the phosphorus load in the Po River (Degobbis et al., 2000) were claimed as principal causes of oligotrophication in the NA (Djakovac et al., 2012).

The advection of different water masses into the Adriatic is potentially one of the main factors affecting the Adriatic ecosystem in general (Civitarese et al., 2010; Vilibić et al., 2012, 2013; Batistić et al., 2014). Changes in phytoplankton communities, which are the first to react to changes in the ecosystem, because of their short life cycle and their position in the food chain, could further influence microbial diversity and activities, with direct influence on the DOC distribution and content
(Wakeham and Lee, 1993). So far, phytoplankton abundance and seasonality in the NA was directly related to the annual regime of the Po River discharge (Viličić et al., 2009; Kraus et al., 2016), while salinity and persistence of different circulation cells (cyclonic and anti-cyclonic) were reported to be the main factor driving the microbial activity in the NA (Orlić et al., 2013; Catalano et al., 2014, and references therein).

Time series in salinity changes, affected by the Po river inflow, the NA circulation (Cozzi and Giani, 2011; Djakovac et al., 2012) and the Adriatic wide-circulation regime controlled by the BiOS (Gačić et al., 2010), indicate that these driving factors are synergistically reinforcing each other. This is evident for the year 2006 (Fig. 4d) and later, when salinity was higher due to both circulation regimes (Oddo and Guarnieri, 2011; Djakovac et al., 2015) and evaporation during the episode of the NA dense water formation (Janeković et al., 2014) that was followed by very low DOC content and accumulation. In the nineties, the situation was completely different, the salinity and DOC appear to be more under the influence of the Po River discharge that brought the freshwater enriched with nutrients (prior to the ban of phosphates-based detergents) and considerable concentration of organic matter to the NA (165-218 $\mu \mathrm{mol} / \mathrm{L}, 1995-2007$, Cozzi and Giani, 2011). However, due to the pronounced seasonal component in the circulation regime (both the local NA and the BiOS) and the Po River discharge rates, the relative importance of these factors that direct impact on biomass and DOC production, changes on monthly, seasonal and inter-annual scales (Gačić et al., 2010, 2014).

Recently, the BiOS was identified as a dominant driver of the Adriatic-wide decadal variability (Mihanović et al., 2015). In support to this hypothesis, our long-term data indicate that DOC in the NA is predominantly under the influence of BiOS. It apparently changes cyclically on timescales between 4 and 11 years (Gačić et al., 2014; Janeković et al., 2014; Mihanović et al., 2015). The extreme and unexpected reversals that were recorded lately are closely related to the formation of the cold and denser Adriatic bottom waters in the NA (extremely dense in years 2006 and 2012). Their formation was, so far, underestimated and appears to be influenced by the ongoing climatic change (Janeković et al., 2014).

Climatic pressures in the Mediterranean, evident by the increase in air (an increase in air temperature of $0.9{ }^{\circ} \mathrm{C}$ was detected in Europe from 1901 to 2005 , with a significant trend since $1980 \mathrm{~s},+0.4{ }^{\circ} \mathrm{C} / \mathrm{de}-$ cade; Alcamo et al., 2007) and seawater temperatures (linear trend of increasing surface temperature in 0-5 $\mathrm{m}$ depth layer in the seawater lake, Rogoznica Lake in central Dalmatia (Croatia) by $1.7^{\circ} \mathrm{C} /$ decade is along the record of other studies in the Adriatic showing a similar trend in the last 50-60 years; Ciglenečki et al., 2015 and references therein), water column stratification (changes in density from 5.0$5.5 \mathrm{~kg} \mathrm{~m}^{3}$ for years $1972-1999$ vs. $4.2-4.5 \mathrm{~kg} \mathrm{~m}^{-3}$ for years $2000-$ 2009 in the NA; Djakovac et al., 2012), water circulation (a decrease in thermohaline circulation in the central Adriatic Sea in years 19522010; Vilibić et al., 2013; changes in the BiOS regimes, Gačić et al., 2010, 2014; Mihanović et al., 2015), seawater acidification (0.05-0.14 pH units in the Western Mediterranean Sea; The MerMex Group et al., 2011, and in the NA dense waters, $0.06 \mathrm{pH}$ units from year 1983 to 2008; Luchetta et al., 2010), the NA dense water formation (extremely dense in 2012, with 30, $6 \mathrm{~kg} / \mathrm{m}^{3}$; Mihanović et al., 2013, Janeković et al., 2014) are expected to highly influence biogeochemical processes and marine ecosystem shifts (see http://www.beringclimate.noaa. gov). Observed and expected changes appear to be visible through the DOC variability.

\section{Conclusions}

The result of this long-term study (25 years, 1989-2015) is a quantitative estimate of the significant inter-annual variability of seawater DOC content at the sampling stations along the transect Po River delta - Rovinj in the NA (Fig. 1). Main findings are: 
1) The existence of the high spatial and temporal trends. In vertical, DOC values decrease with the seawater depth. In horizontal, DOC values decrease from the west of the basin to the east coast. A dominant temporal variability is on the seasonal and inter-annual scales, with DOC decreasing trend in all water layers and all seasons. The seasonal cycle is the most prominent in the surface layer, with DOC accumulation during the summer and DOC depletion during the winter months. The spring and autumn are transitional periods. Above the confirmation of these previously known patterns, the evident significant inter-annual variability, that periodically could turn the oligotrophic system into eutrophic, emphasize the importance for the continuous DOC monitoring in the future.

2) Several factors are affecting the DOC distribution in the NA. Dominant are the hydrographic conditions and water circulation that are under the strong impact of the already reported anthropogenic and climatic variabilities. The variability of DOC seems to be influenced by the local and global conditions that include variable freshwater discharge, mainly by the Po River, and changes in the circulation patterns directed by the orography and sea-land interactions as a part of the global change.

3) Variability of the seawater DOC content is strongly related to salinity changes. The DOC results for the period 1994-2006 are well correlated with the analysis of the meteorological conditions and the geostrophic circulation, particularly for the type B winters (Supić et al., 2012). These winters were characterized with the lower Po River impact and the higher influence of the waters from the southern Adriatic.

4) DOC variability in the NA is a good proxy for the BiOS. For the first time, on the yearly basis, it is shown that DOC oscillations in the NA seem to be strongly related to the large-scale variability in the upper water layer circulation regimes of the Ionian Sea, driven by the feedback mechanism, the BiOS. From the altimetric data, the occurrence of two anti-cyclonic phases (1987-1997 and 2006-2010) and two cyclonic phases (1998-2005 and 2011-2012) was identified in the Ionian Sea (Gačić et al., 2014, Vilibić personal communication) that coincide precisely with the DOC data presented in Fig. 4b and Graphical abstract. From year 1991 to year 1998 the anti-cyclonic BiOS, with a flow of the water carrying rich nutrients from the western Mediterranean, was anomalously strong resulting in the higher DOC values. In years that followed (1998-2006) the BiOS was cyclonic bringing the seawater with lower concentrations of nutrients thus potentially reducing the DOC content. From 2006 to 2010/2011 the anti-cyclonic circulation again coincided with the increased DOC values. Since year 2011, the cyclonic BiOS was not as strong as in years 1998-2006, resulting in the neutral DOC trend (data in the Graphical abstract). Preliminary statistical models have shown significant difference in the DOC content in the years with different regimes of the BiOS circulation and the Po River influence. However, a further work is planned to generate a more detailed association.

5) A good agreement was obtained with the results from other studies that used different variables to monitor the environmental changes that occurred as a consequence of the climatic forcing. Results from this study indicate that DOC could be an invaluable tool serving as a potential indicator of global climate change. This emphasizes further the importance of the long-term monitoring as conducted in this study.

\section{Acknowledgements}

The study presented in this paper was funded by the following Projects: 1) Project "Adriatic" (1998-2011) and "Nature of organic matter and interaction with traces and surfaces in the environment" funded by the Ministry of Science, Education and Sports of the Republic of Croatia, 098-0982934-2717 (2007-2013); 2) MAT project "Mucilages and the Adriatic and Tyrrhenian seas" funded by the Italian Ministry of Environment (1998-2002); 3) "Sulphur and Carbon dynamics in the marine and fresh water environment" (SPHERE) funded by the Croatian Science Foundation, IP-11-2013-1205 (2014-2018). The authors acknowledge contribution of Z. Kodba and Z. Zovko during the sampling and measurements as well as the Center for Marine Research Rovinj, Rudjer Boskovic Institute, Rovinj, Republic of Croatia for providing the salinity and temperature data; the crew of the research vessel Vila Velebita, Center for Marine Research Rovinj, Rudjer Boskovic Institute, Rovinj, Republic of Croatia for the technical assistance during the sampling. The authors also thank I. Janeković and I. Vilibić for valuable discussions of BiOS circulation, and anonymous reviewers for valuable comments that improved the paper.

\section{Appendix A. Supplementary data}

Supplementary data to this article can be found online at http://dx. doi.org/10.1016/j.scitotenv.2017.02.111.

\section{References}

Alcamo, J., Moreno, J.M., Nováky, B., Bindi, M., Corobov, R., Devoy, R.J.N., Giannakopoulos, C., Martin, E., Olesen, J.E., Shvidenko, A., 2007. Europe climate change 2007: impacts, adaptation and vulnerability. In: Parry, M.L., Canziani, O.F., Palutikof, J.P., van de Linden, P.J., Hanson, C.E. (Eds.), Contribution of Working Group II to the Fourth Assessment Report of the Intergovernmental Panel on Climate Change. Cambridge University Press, Cambridge, UK, pp. 541-580.

Artegiani, A., Bregant, D., Paschini, E., Pinardi, N., Raicich, F., Russo, A., 1997. The Adriatic Sea general circulation. Part I. Air-sea interaction and water mass structure. J. Phys. Oceanogr. 27, 1492.

Avril, B., 2002. DOC dynamics in the northwestern Mediterranean Sea (DYFAMED site). Deep-Sea Res. II 49, 2163.

Batistić, M., Garić, R., Molinero, J.C., 2014. Interannual variations in Adriatic Sea zooplankton mirror shifts in circulation regimes in the Ionian Sea. Clim. Res. 61, 231

Berto, D., Giani, M., Savelli, F., Centanni, E., Ferrari, C.R., Pavoni, B., 2010. Winter to spring variations of chromophoric dissolved organic matter in a temperate estuary (Po River, northern Adriatic Sea). Mar. Environ. Res. 70, 73.

Catalano, G., Azzaro, M., Bastianini, M., Bellucci, L.G., Bernardi, Aubry, Bianchi, F., Burca, M. Cantoni, C., Caruso, G., Casotti, R., Cozzi, S., Del Negro, P., Fonda Umani, S., Gian, M., Giuliani, S., Kovacevic, V., La Ferla, R., Langone, L., Luchetta, A., Monticelli, L.S. Piacentino, S., Pugnetti, A., Ravaioli, M., Socal, G., Spagnoli, F., Ursella, L., 2014. The carbon budget in the northern Adriatic Sea, a winter case study. J. Geophys. Res. http:// dx.doi.org/10.1002/2013JG002559.

Cauwet, G., 1994. HTCO method for dissolved organic carbon analysis in seawater: influence of catalyst on blank estimation. Mar. Chem. 47, 55.

Cauwet, G., 1999. Determination of dissolved organic carbon and nitrogen by high temperature combustion. In: Grasshoff, K., Kremling, K., Ehrhardt, M. (Eds.), Methods of Seawater Analysis. Wiley-WCH Verlag GmbH, D-69469 Weinheim, pp. 407-421.

Church, M.J., Ducklow, H.W., Karl, D.M., 2002. Multiyear increases in dissolved organic matter inventories at Station ALOHA in the North Pacific Subtropical Gyre. Limnol Oceanogr. 47 (1), 1.

Ciglenečki, I., Ćosović, B., Vojvodić, V., Plavšić, M., Furić, K., Minacci, A., Baldi, F., 2000. The role of reduced sulfur species in the coalescence of polysaccharides in the Adriatic Sea. Mar. Chem. 71, 233.

Ciglenečki, I., Plavšić, M., Vojvodić, V., Ćosović, B., Pepi, M., Baldi, F., 2003. Polysaccharide transformation by sulfide in diatom culture and natural mucilage. Mar. Ecol. Prog. Ser. 263, 17.

Ciglenečki, I., Janeković, I., Marguš, M., Bura-Nakić, E., Carić, M., Ljubešić, Z., Batistić, M., Dupčić, I., Hrustić, E., Garić, R., 2015. Impacts of extreme weather events on highly eutrophic marine ecosystem (Rogoznica Lake, Adriatic coast). Cont. Shelf Res. 108, 144.

Civitarese, G., Gačić, M., Lipizer, M., Eusebi Borzelli, G.L., 2010. On the impact of the Bimodial Oscillating System (BiOS) on the biogeochemistry and biology of the Adriatic and Ionian Seas (Eastern Mediterranean). Biogeosciences 7, 3987.

Colella, S., Falcini, F., Rinaldi, E., Sammartino, M., Santoleri, R., 2016. Mediterranean Ocean Colour Chlorophyll Trends. PloS One http://dx.doi.org/10.1371/journal.pone. 0155756.

Ćosović, B., Vojvodić, V., 2000. Mucilage events in the Northern Adriatic: search for tools and early warning. Period. Biol. 102-1, 255.

Cozzi, S., Giani, M., 2011. River water and nutrient discharges in the Northern Adriatic Sea: current importance and long-term changes. Cont. Shelf Res. 31, 1881.

Dafner, E.V., Wangersky, P.J., 2002. A brief overview of modern directions in marine DOC studies part II-recent progress in marine DOC studies. J. Environ. Monit. 4, 55

De Vittor, C., Paoli, A., Fonda Umani, S., 2008. Dissolved organic carbon variability in a shallow coastal marine system (Gulf of Trieste, northern Adriatic Sea). Estuar. Coast. Shelf Sci. 78, 280.

Degobbis, D., Precali, R., Ivancic, I., Smodlaka, N., Fuks, D., Kveder, S., 2000. Long-term changes in the northern Adriatic ecosystem related to anthropogenic eutrophication. Int. J. Environ. Pollut. 13, 495.

Ducklow, H.W., 2002. Foreword. In: Hansell, D.A., Carlson, C.A. (Eds.), Biogeochemistry of Marine Dissolved Organic Matter. Academic Press, San Diego, pp. XV-xix.

Ducklow, H.W., Doney, C.D., Steinberg, D.K., 2009. Contributions of long-term research and time-series observations to marine ecology and biogeochemistry. Annu. Rev. Mar. Sci. 1, 279. 
Djakovac, T., Degobbis, D., Supic, N., Precali, R., 2012. Marked reduction of eutrophication pressure in the northeastern Adriatic in the period 2000-2009. Estuar. Coast. Shelf Sci. $115,25$.

Djakovac, T., Supić, N., Bernardi Aubry, F., Degobbis, D., Giani, M., 2015. Mechanisms of hypoxia frequency changes in the northern Adriatic Sea during the period 1972 2012. J. Mar. Syst. 141, 179.

Enders, C.K., Tofighi, D., 2007. Centering predictor variables in cross-sectional multilevel models: a new look at an old issue. Psychol. Methods 12:121. http://dx.doi.org/10. 1037/1082-989X.12.2.12.

Fonda Umani, S., Milani, L., Borme, D., de Olazabal, A., Parlato, S., Precali, R., Kraus, R., Lučić D., Njire, J., Totti, C., Romagnoli, T., Pompei, M., Cangini, M., 2005. Inter-annual variations of planktonic food webs in the northern Adriatic Sea. Sci. Total Environ. 353, 218.

Fonda Umani, S., Del Negro, P., Larato, C., De Vittor, C., Cabrini, M., Celio, M., Falconi, C., Tamberlich, F., Azam, F., 2007. Major inter-annual variations in microbial dynamic in the Gulf of Trieste (northern Adriatic Sea) and their ecosystem implications. Aquat. Microb. Ecol. 46, 163.

Gačić, M., Eusebi Borzelli, G.L., Civitarese, G., Cardin, V., Yari, S., 2010. Can internal processes sustain reversals of the ocean upper circulation? The Ionian Sea example. Geophys. Res. Lett. 37. http://dx.doi.org/10.1029/2010GL043216.

Gačić, M., Civitarese, G., Kovačević, V., Ursella, L., Bensi, M., Menna, M., Cardin, V., Poulain, P.-M., Cosoli, S., Notarstefano, G., Pizzi, C., 2014. Extreme winter 2012 in the Adriatic: an example of climatic effect on the BiOS rhythm. Ocean Sci. 10, 513.

Gašparović, B., 2012. Decreased production of surface-active organic substances as a consequence of the oligotrophication in the Northern Adriatic Sea. Estuar. Coast. Shelf Sci. $115,33$.

Giani, M., Savelli, F., Berto, D., Zangrando, V., Ćosović, B., Vojvodić, V., 2005. Temporal dynamics of dissolved and particulate organic carbon in the northern Adriatic Sea in relation to the mucilage. Sci. Total Environ. 353, 126.

Giani, M., Đakovac, T., Degobbis, D., Cozzi, S., Solidoro, C., Fonda Umani, S., 2012. Recent changes in the marine ecosystems of the northern Adriatic Sea. Estuar. Coast. Shelf Sci. $115,1$.

Grbec, B., Morović, M., Kušpilić, G., Matijević, S., Matić, F., Beg Paklar, G., Ninčević, Ž., 2009. The relationship between the atmospheric variability and productivity in the Adriatic Sea area. J. Mar. Biol. Assoc. U. K. 89 (8), 1549.

Hansell, D.A., Carlson, C.A., 2001. Marine dissolved organic matter and the carbon cycle. Oceanography 14-4, 41 (Special issue JGOFS).

Hansell, D.A., Carlson, C.A. (Eds.), 2015. Biogeochemistry of Marine Dissolved Organic Matter, second ed. Academic Press Elsevier, p. 693.

Harding, L.W., Degobbis, D., Precali, R., 1999. Production and fate of phytoplankton: annual cycles and interannual variability. In: Malone, T.C., Malej, A., Harding, L.W., Smodlaka, N., Turner, R.E. (Eds.), Ecosystems at the Land-Sea Margin: Drainage Basin to Coastal Sea. American Geophysical Union, Washington, D.C., pp. 131-172.

Hofmann, D.A., Gavin, M.B., 1998. Centering decisions in hierarchical linear models: implications for research in organizations. J. Manag. 24, 623.

IPCC, 2013. Climate change: the physical science basis. Working group I contribution to the fifth assessment report of the intergovernmental panel on climate change, summary for policymakers. In: Stocker, T.F., Qin, D., Plattner, G.-K., MMB, Tignor, Allen, S.K., Boschung, J., Nauels, A., Xia, Y., Bex, V., Midgley, P.M. (Eds.), Working Group Technical Support Unit, October 2013.

Iveša, Lj, Djakovac, T., Devescovi, M., 2016. Long-term fluctuations in Cystoseira populations along the west Istrian Coast (Croatia) related to eutrophication patterns in the northern Adriatic Sea. Mar. Pollut. Bull. 106, 162

Janeković, I., Mihanović, H., Vilibić, I., Tudor, M., 2014. Extreme cooling and dense water formation estimates in open and coastal regions of the Adriatic Sea during the winter of 2012. J. Geoph. Res. Oceans http://dx.doi.org/10.1002/2014JC009865.

Kraus, R., Supić, N., 2011. Impact of circulation on high phytoplankton blooms and fish catch in the northern Adriatic (1990-2004). Estuar. Coast. Shelf Sci. 91, 198.

Kraus, R., Supić, N., Precali, R., 2016. Factors favouring large oceanic production in the northern Adriatic: towards the northern Adriatic empirical ecological model. Ocean Sci. 12, 19.

Landis, J.R., Koch, G.G., 1977. The measurement of observer agreement for categorical data. Biometrics 33, 159 .

Littell, R.C., Milliken, G.A., Stroup, W.W., Wolfinger, R.D., 1996. SAS System for Mixed Models. SAS Institute Inc., Cary, NC.

Luchetta, A., Cantoni, C., Catalano, G., 2010. New observations of $\mathrm{CO}_{2}$-induced acidification in the northern Adriatic Sea over the last quarter century. Chem. Ecol. 26, 1.

Marić, D., Kraus, R., Godrijan, J., Supić, N., Đakovac, T., Precali, R., 2012. Phytoplankton response to climatic and anthropogenic influence in the northeastern Adriatic during the last four decades. Estuar. Coast. Shelf Sci. 115, 98.

Marić, D., Frka, S., Godrijan, J., Tomažić, I., Penezić, A., Đakovac, T., Vojvodić, V., Precali, R., Gašparović, B., 2013. Organic matter production during late summer-winter period in a temperate sea. Cont. Shelf Res. 55, 52.

Mihanović, H., Vilibić, I., Carniel, S., Tudor, M., Russo, A., Bergamasco, A., Bubić, N., Ljubešić, Z Viličić, D., Boldrin, A., Malačić, V., Celio, M. Comici, C., Raicich, F. 2013. Exceptional dense water formation on the Adriatic shelf in the winter of 2012. Ocean Sci. 9, 561.
Mihanović, H., Vilibić, I., Dunić, N., Šepić, J., 2015. Mapping of decadal middle Adriatic oceanographic variability and its relation to the BiOS regime. J. Geoph. Res. Oceans http://dx.doi.org/10.1002/2015JC010725.

Mozetič, P., Solidoro, C., Cossarini, G., Socal, G., Precali, R., Francé, J., Bianchi, F., De Vittor, C. Smodlaka, N., Fonda Umani, S., 2010. Recent trends towards oligotrophication of the Northern Adriatic: evidence from chlorophyll a time series. Estuar. Coasts 33, 362.

Noone, K.J., Sumaila, U.R., Diaz, R.J. (Eds.), 2013. Managing Ocean Environments in a Changing Climate (Sustainability and Economic Perspectives I). Elsevier.

Oddo, P., Guarnieri, A., 2011. A study of the hydrographic conditions in the Adriatic Sea from numerical modelling and direct observations (2000-2008). Ocean Sci. 7, 549.

Orlić, S., Najdek, M., Supić, N., Ivančić, I., Fuks, D., Blažina, M., Šilović, T., Paliaga, P., Godrijan, J., Marić, D., 2013. Structure and variability of microbial community at transect crossing a double gyre structure (north-eastern Adriatic Sea). Aquat. Microb. Ecol. 69, 193.

Pettine, M., Patrolecco, L., Manganelli, M., Capri, S., Farrace, M.G., 1999. Seasonal variations of dissolved organic matter in the northern Adriatic Sea. Mar. Chem. 64-3, 153.

Pettine, M., Capri, S., Manganelli, M., Patrolecco, L., Puddu, A., Zoppini, A., 2001. The dynamics of DOM in the northern Adriatic Sea. Estuar. Coast. Shelf Sci. 52, 471.

Polimene, L., Pinardi, N., Zavatarelli, M., Allen, J.I., Giani, M., Vivhi, M., 2007. A numerical simulation study of dissolved organic carbon accumulation in the northern Adriatic Sea. J. Geophys. Res. 112:C03S20. http://dx.doi.org/10.1029/2006JC003529.

Revelante, N., Gilmartin, M., 1983. The phytoplankton of the Adriatic Sea: community structure and characteristics. Thalass. Jugosl. 19, 303.

Schiano, M.E., Sparnocchia, S., Cappa, C., Bozzano, R., 2005. An analysis of the climate variability over the Mediterranean sea by means of the surface water vapour density. Int. J. Climatol. 25, 1731

Sellner, K.G., Fonda-Umani, S., 1999. Dinoflagellate blooms and mucilage production. In: Malone, T.C., Malej, A., Harding, L.W., Smodlaka, N., Turner, R.E. (Eds.), Ecosystems at the Land-Sea Margin: Drainage Basin to Coastal Sea. American Geophysical Union, Washington, D.C., pp. 173-206.

Sharp, J.H., Benner, R., Bennet, L., Carlson, C.A., Fitzwater, S.E., Peltzer, E.T., Tupas, L.M., 1995. Analyses of dissolved organic carbon in seawater: the JGOFS EqPac methods comparison. Mar. Chem. 48, 91.

Solidoro, C., Bastianini, M., Bandelj, V., Codermatz, R., Cossarini, G., Melaku Canu, D., Ravagnan, E., Salon, S., Trevisani, S., 2009. Current state, scales of variability, and trends of biogeochemical properties in the northern Adriatic Sea. J. Geophys. Res. 114:C07S91. http://dx.doi.org/10.1029/2008JC004838.

Supić, N., Orlić, M., Degobbis, D., 2000. Istrian coastal countercurrent and its year-toyearvariability. Estuar. Coast. Shelf Sci. 50, 385

Supić, N., Kraus, R., Kuzmić, M., Paschini, E., Precali, R., Russo, A., Vilibić, I., 2012. Predictability of northern Adriatic winter conditions. J. Mar. Syst. 90, 42.

Tepić, N., Gašparović, B., Ahel, M., 2009. Multivariate statistical analysis of the distribution patterns of carbohydrates and surface-active substances in the northern Adriatic Sea. Mar. Chem. 114, 37.

The MerMex Group, Durrieu de Madron, X., Guieu, C., Sempéré, R., Conan, P., Cossa, D., D'Ortenzio, F., Estournel, C., Gazeau, F., Rabouille, C., Stemmann, L., et al., 2011. Marine ecosystems' responses to climatic and anthropogenic forcings in the Mediterranean. Prog. Oceanogr. 91, 97.

Vilibić, I., Matijević, S., Šepić, J., Kušpilić, G., 2012. Changes in the Adriatic oceanographic properties induced by the Eastern Mediterranean Transient. Biogeosciences 9, 2085.

Vilibić, I., Šepić, J., Proust, N., 2013. Weakening thermohaline circulation in the Adriatic Sea. Clim. Res. 55, 217

Viličić, D., Đakovac, T., Burić, Z., Bosak, S., 2009. Composition and annual cycle of phytoplankton assemblages in the northeastern Adriatic Sea. Bot. Mar. 52, 291.

Vojvodić, V., Ćosović, B., 1996. Fractionation of surface active substances on the XAD-8 resin: Adriatic Sea samples and phytoplankton culture media. Mar. Chem. 54, 119.

Vollenweider, R.A., Rinaldi, A., 1995. Marine mucilages with special reference to mucilage events in the northern Adriatic Sea, the Thyrrhenian Sea and North Sea. Sci. Total Environ. 165,165

Wakeham, S.G., Lee, C., 1993. Production, transport and alteration of particulate organic matter in the marine water column. In: Engel, M.H., Macko, S.A. (Eds.), Organic Geochemistry. Plenum Press, New York, pp. 145-169.

Williams, P.J., Bauer, J., Benner, R., Hegeman, J., Ittekkot, V., Miller, A., Norrman, B., Suzuki, Y., Wangersky, P., McCarthy, M., 1993. Measurement of dissolved organic carbon and nitrogen in natural waters. Mar. Chem. 41, 1.

Wu, Y., Zhu, Z., Bao, H., Gan, S., Zhang, J., 2015. Organic matter and biomarkers of the Changjiang Estuary and East China Sea Shelf. In: Zhang, Jing (Ed.), Ecological Continuum Form the Changiiang (Yangtze River) Watersheds to the East China Sea Continental Margin. Springer, pp. 119-135.

Zavatarelli, M., Raicich, F., Bregant, D., Russo, A., Artegiani, A., 1998. Climatological biogeochemical characteristics of the Adriatic Sea. J. Mar. Syst. 18, 227.

Zoppini, A., Pettine, M., Totti, C., Puddu, A., Artegiani, A., Pagnotta, R., 1995. Nutrients, standing crop and primary production in western coastal waters of the Adriatic sea. Estuar. Coast. Shelf Sci. 41 (5), 493. 